\title{
Mergers and acquisitions in emerging markets: What drives absorptive capacity in target firms?
}

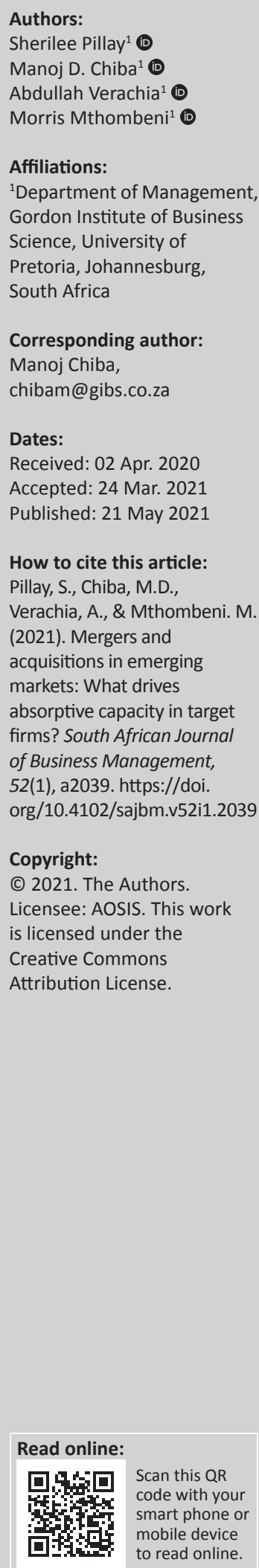

Purpose: The purpose of this study was to investigate how knowledge flow and productivity affect the absorptive capacity of target firms in emerging markets.

Design/methodology/approach: We used self-administered questionnaires to measure absorptive capacity, knowledge flow and productivity constructs. The sample comprised individuals who were employees of firms that completed acquisitions between 2015 and 2017. The acquisitions were publicly announced and the target firms were all in emerging markets.

Findings/results: Firstly, our results confirmed the multidimensional nature of absorptive capacity. Secondly, we found a positive correlation between a target firm's knowledge flow and productivity and its absorptive capacity. Thirdly, our results indicated that knowledge flow and operational processes will support the introduction and integration of external knowledge into a target firm. Therefore, understanding the absorptive capacity of target firms is central to the ability of new and existing knowledge to be assimilated.

Practical implications: The realisation of the strategic intent of an acquisition is dependent on effective knowledge flow, supported by efficient communication and operational processes. The target firm's absorptive capacity is, therefore, a key consideration for acquiring firms. Understanding this will be useful for firms to consider acquisitions of target firms in emerging markets and could potentially enhance their chances of success.

Originality/value: This study contributes to the limited body of research on emerging market merger and acquisition activity. It responds to the call for further research to be conducted on emerging markets and the role of absorptive capacity in realising the strategic intent of acquisitions.

Keywords: absorptive capacity; knowledge flow; productivity; target firm; emerging markets.

\section{Introduction}

Although mergers and acquisitions (M\&A) are a common internationalisation strategy, firms' weak absorptive capacity can lead to poor implementation of, or negative performance from M\&A perspective - a phenomenon that has long been of interest to management scholars (Ahammad, Tarba, Liu, \& Glaister, 2016; Bernad, Fuentelsaz, \& Gómez, 2010; Ferreira, Santos, De Almedia, \& Reis, 2014).

Absorptive capacity can be defined as a '... capability that [essentially] resides within employees of an organisation ...' (Junni \& Sarala, 2013, p. 420), and '... consists of the ability and motivation of the organisational members to access and make use of external knowledge ...' (Junni \& Sarala, 2013, p. 421). Many view absorptive capacity as crucial for successful M\&A activity because it facilitates the integration of internal knowledge with acquired knowledge, allowing synergies to be identified and leveraged to deliver optimal value (Cohen \& Levinthal, 1990; Junni \& Sarala, 2013; Nair, Demirbag, \& Mellahi, 2016; Wang \& Wang, 2015; Zahra \& George, 2002). The ability to successfully introduce, integrate and assimilate newly acquired knowledge resources is one of the cornerstones of absorptive capacity.

Despite the scholarly interest, little is known about the role of absorptive capacity in target firms in emerging markets (EMs). Simply generalising attributes that influence EM firms' absorptive capacity from findings in developed economies may be misleading (Khan, Rao-Nicholson, Akhtar, \& He, 2017; Xie, Reddy, \& Liang, 2017). This questionable approach is exacerbated by the general paucity of managerial skills in EMs such as South Africa (Department of Higher Education and Training, 2019; Nienaber, 2007; Radipere \& Scheers, 
2005). Rezaei-Zadeh and Darwish (2016) indicated that firms must have suitable managerial skills and processes in place so that knowledge can be organised, integrated and assimilated to enhance the firms' absorptive capacity. The absence of managerial skills therefore constitutes a barrier to building a firm's absorptive capacity (Deng \& Yang, 2015; Li, Li, \& Wang, 2016; Zahra \& George, 2002).

Knowledge is a key resource in a target firm during an acquisition. It is a driver of cross-border acquisitions because the development of local knowledge and capabilities by acquiring firms is time-consuming, whereas the acquisition of already existing assets is more efficient (Junni \& Sarala, 2013). The value of acquired resources, however, only becomes evident when knowledge is received and embedded in a target firm's operation (Mukherji, Mukherji, Dibrell, \& Francis, 2013). To create absorptive capacity, there needs to be knowledge flow (communication, processes and skills) and productivity (implementation of processes and operational processes). Thereafter, practices need to be established to continually review knowledge for relevance and appropriate application (Lane \& Lubatkin, 1998; Zahra \& George, 2002).

Knowledge flows within and into a target firm stimulate the firm's absorptive capacity, thereby enabling the firm to creatively adapt internal and acquired external knowledge resources to create value (Martín-de Castro, 2015). Sears and Hoetker (2014) asserted that the integration of the target firm's and the acquiring firm's knowledge set is a precursor to value creation. Knowledge flows into a target firm require a 'linkage' or effective processes to be in place (Nair et al., 2016; Najafi-Tavani, Robson, Zaefarian, Andersson, \& Yu, 2018). This 'linkage' allows knowledge to flow efficiently within the target firm, thereby creating a larger pool of knowledge that is directed at realising the intended outcome from the acquisition.

Knowledge flow, as the foundation of absorptive capacity, demands effective operational capacity during the acquisition phase (Bernad et al., 2010; Nair et al., 2016). Cummins and Xie (2008) argued that it is preferable to acquire efficiently run target firms that possess competencies in focused areas, as this will allow the immediate application of knowledge for commercial benefit. Schiffbauer, Siedschlag and Ruane (2017) showed that foreign investors set out to acquire the bestperforming firms because enhanced productivity in target firms might not be the natural consequence of foreign ownership (Bernad et al., 2010; Cummins \& Xie, 2008). Therefore, target firms should already be productive so that absorptive capacity can be efficiently unleashed and value created (Oldford \& Otchere, 2016; Stiebale \& Vencappa, 2018).

This study explores the influence of two critical factors on a target firm's absorptive capacity in an EM: knowledge flow and productivity. This study contributes to the M\&A literature because these two critical influences will determine whether acquisitions ultimately deliver on firms' strategic intent.

\section{Literature review}

Emerging market acquirers seek to complement their capabilities and knowledge resources, thereby compensating for their potential EM deficiencies (Stiebale \& Vencappa, 2018; Xie et al., 2017; Yao, Yang, Fisher, Ma, \& Fang, 2013). Cummins and Xie (2008) discussed the popularity of crossborder acquisitions in the property and insurance sector, where insurance groups pursue acquisitions to enhance revenue. In addition, through the coordination of inventory systems and supply chains, they create synergies that clear the way for acquisitions (Çömez-Dolgan \& Tanyeri, 2015). Deng and Yang (2015) emphasised that, in line with the resource-based theory, resources are unique assets used in implementing value-creating strategies. Such assets and synergies enhance performance and profitability in new or existing markets (Ahammad et al., 2016; Bauer, Matzler, \& Wolf, 2016; Rahman \& Lambkin, 2015; Xie et al., 2017). If these resources are to be effectively leveraged, the firm must have the capabilities to integrate, learn from and reconfigure internal and external resources in environments such as emerging economies (Teece, 2016).

The acquisition of target firms in EM tends to result in weak transfers of knowledge across industries and between foreign and local firms, owing to the presence of limited skills (Sarala, Junni, Cooper, \& Tarba, 2016;) and ineffective processes and policies (Khan et al., 2017; Lebedev, Peng, Xie, \& Stevens, 2015; Nair et al., 2016; Osabutey, Williams, \& Debrah, 2014). Nevertheless, globalisation and privatisation have sparked a wave of acquisitions of EM firms (Xie et al., 2017). Emerging markets are becoming increasingly important targets for trade and foreign direct investment (FDI) because of the opportunities for business growth (Deng \& Yang, 2015). Despite this, M\&A in EM has attracted less research attention than M\&A in developed markets. This suggests that more research is needed on target firms in EMs specifically (Du \& Boateng, 2012; Ferreira et al., 2014).

Lin, Peng, Yang and Sun (2009) asserted that institutional weaknesses and a lack of transparency in EM may result in smaller, more volatile and less liquid markets, thus reducing the prospects of M\&A being successful (Chen, Hua, \& Boateng, 2017; Du \& Boateng, 2012). Underdeveloped institutions trigger concerns about currency expropriation, operational risks and general transactional uncertainty, which could impede successful acquisitions (Acemoglu \& Johnson, 2005; Estrin \& Prevezer, 2011).

The study discussed in this article answers the call of Nair et al. (2016) for a better understanding of firm's characteristics in countries targeted for acquisition. Since cross-border acquisition deals can produce significant gains, as seen in acquisition examples in India (Nicholson \& Salaber, 2013), these additional insights will aid the acquisition process in general.

The absorptive capacity of the target firm is a crucial consideration in acquisition decisions (Du \& Sim, 2016; Junni \& Sarala, 2013). It has three dimensions: the introduction 
of external knowledge into the firm; the integration of newly acquired knowledge with existing knowledge and the assimilation of the acquired knowledge for commercial application (Cohen \& Levinthal, 1990; Martín-de Castro, 2015; Zahra \& George, 2002). Each dimension influences the effective use of knowledge resources.

Acquired knowledge needs to be identified and diffused by and within the target firm. In the process of introducing and integrating knowledge, target firms will assess the relevance of the knowledge in terms of its implications, potential synergies and benefits (Nair et al., 2016; Yahiaoui, Chebbi, \& Weber, 2016). This could affect the assimilation of knowledge as the acquired knowledge may impact current processes, the cost of new processes and resource and skills requirements (Bernad et al., 2010; Buckley, Munjal, Enderwick, \& Forsans, 2016; Cummins \& Xie, 2008).

Martín-de Castro (2015) argued that to assimilate acquired knowledge, the target firm needs to have the capabilities to analyse, process and interpret it so that it can be utilised effectively. Junni and Sarala (2013), in turn, stressed the importance of probing underexplored influences on, and outcomes of, absorptive capacity at the target firm for successful acquisitions. The following factors have been shown to significantly influence a firm's absorptive capacity: cultural fit (Li et al., 2016), existing regulations, geographical (Nicholson \& Salaber, 2013) or historical country dynamics (Junni \& Sarala, 2013), employee behaviour (Bertrand \& Capron, 2015; Oldford \& Otchere, 2016; Zahra \& George, 2002), communication, staff retention (Bauer et al., 2016; Wang \& Wang, 2015), productivity (Ahammad et al., 2016), organisational and integration processes (Yao et al., 2013) and knowledge transfer (Sears \& Hoetker, 2014). However, no differentiation has been made between the effects of these factors on the absorptive capacity of acquiring firms and target firms, respectively.

Du and Sim (2016) argued that it is crucial to understand the effects of acquisitions on target and acquiring firms individually. Junni and Sarala (2013) produced empirical evidence that target firms' knowledge-processing systems influence their absorptive capacity but such systems had no effect on the absorptive capacity of the acquiring firm. The same outcome could be seen in research conducted in the financial sector where, despite the acquiring firm and target firms being regarded as the same, different results were achieved (Mukherji et al., 2013; Stahl et al., 2013).

Target firms undergo more extensive restructuring than the acquiring firm and tend to react negatively to acquisitions. This is because target firm employees struggle to retain their identity and may even be less efficient after the acquisition (Du \& Sim, 2016). It is imperative for target firms to understand the extent to which they can absorb knowledge through their employees, as this is an acknowledged source of advantage and way of realising an acquisition's strategic intent (Cohen \& Levinthal, 1990; Najafi-Tavani et al., 2018;
Volberda, Foss, \& Lyles, 2010). Cohen and Levinthal (1990) reported that absorptive capacity depends on the efforts of employees and the firm's ability to effectively utilise their acquired knowledge. Insufficient effort on the part of employees because of a lack of motivation and/or ability, could negatively impact performance and derail an acquisition. (Sears \& Hoetker, 2014)

Andersson, Dasí Mudambi and Pederson (2016) illustrated that performance is dependent on the efficient redeployment of complementary resources between the acquiring and target firm. This will allow acquired resources and capabilities to be effectively utilised by both the acquiring and target firm, thus enhancing their absorptive capacity. Teece (2016) proposed the concept of dynamic capabilities theory to address 'the crucial role of capabilities to integrate, learn and reconfigure internal and external resources...' Dynamic capabilities theory provides for the strategic use of a firm's capabilities to enhance value (Di Stefano, Peteraf, \& Verona, 2014). Therefore, while the strategic intent behind an acquisition is an important driver in an acquisition, this must be supported by the capability of converting knowledge resources into productive outcomes. It is suggested that this required capability is the target firm's absorptive capacity.

\section{Absorptive capacity and knowledge flow}

Achieving effective knowledge flow largely involves seamlessly transplanting knowledge into a target firm (Hurtado-Ayala \& Gonzalez-Campo, 2015; Najafi-Tavani et al., 2018). Absorptive capacity is regarded as a supportive tool in the mobilisation of knowledge flow as it incorporates processes to introduce, integrate and assimilate knowledge into the firm. Khan et al. (2017), Najafi-Tavani et al. (2018) and Nicholson and Salaber (2013) likened absorptive capacity to a moderator between the flow of knowledge and target firms. To achieve such knowledge flow, Junni and Sarala (2013) showed that knowledge-processing systems are needed, supported by intercompany communication and teamwork and effective infrastructure.

Acquiring firms must ensure that there are effective communication channels within target firms because these will provide a necessary pathway for the flow of knowledge (Liu, Gao, Lu, \& Lioliou, 2016), and facilitate the integration and assimilation of acquired knowledge (Rezaei-Zadeh \& Darwish, 2016). Research has shown that there should also be social interactions between and within the acquiring and target firms, which will create another channel through which knowledge can flow (Liu et al., 2016). Social interactions create cross-functional ties and connectedness, strengthening the trust and familiarity between the firms and their employees.

Trust enables employees to draw on previous experiences and share know-how, thereby facilitating the externalisation of knowledge. Research completed by Rezaei-Zadeh and Darwish (2016) emphasised the importance of the 
acquiring and target firms communicating and interacting continually to encourage shared practices and mutually beneficial outcomes.

Familiarity is seen to reduce possible tension that arise between the acquiring and target firms, which hinders the integration process (Khan et al., 2017; Nair et al., 2016). The transmission of acquired knowledge within the firms streamlines knowledge integration and assimilation. Li et al. (2016) provided evidence that effective knowledge transfer and communication stimulate absorptive capacity, which in turn paves the way for the effective integration of the acquiring and target firm. Building on the research by Li et al. (2016), Najafi-Tavani et al. (2018) argued that acquiring firms should devote enough time and resources to promoting knowledge flow into target firms, ensuring that the latter have the capability to absorb such knowledge.

Knowledge acquisition and dissemination are critical enablers of a firm's ability to sense, seize and exploit opportunities (Nieves \& Haller, 2014; Wang \& Ahmed, 2007). Zahra, Nielsen and Bogner (1999) argued that it is not sufficient to simply gather and share information; it also needs to be integrated and combined to create new opportunities that can be exploited. Nielsen (2006) asserted that the survival of firms is not premised on how knowledge is accumulated, but rather how it is exploited, which includes acquiring new knowledge.

Dynamic capabilities refer not only to how firms leverage their existing resource base, but also to how they identify and exploit new resources (Teece, 2007). Leveraging knowledge can boost firms' competitive advantage (Hamel \& Prah, 1994; Wang \& Ahmed, 2004). International acquisition is a critical element in the process of accessing new resource bases. At the same time, employees in the target firm need to have the appropriate skills to leverage the acquired knowledge when making decisions (Chen et al., 2017; Stiebale \& Vencappa, 2018). The literature reports that the skills involved in undertaking joint tasks or projects, as well as collective teaching (employees observing the employees of the other firm) and direct observation (the knowledge embedded in daily routines and interactions with employees) are some of the ways of stimulating knowledge flow (Najafi-Tavani et al., 2018; Sarala et al., 2016).

This study suggests that effective knowledge flow influences the absorptive capacity of an EM target firm because the diffusion of knowledge across the firm stimulates its use for suitable endeavours and outcomes. The target firm is thus able to make decisions based on the consolidated knowledge in circulation, with a view to realising the strategic intent of the acquisition.

\section{Absorptive capacity and productivity}

Absorptive capacity can be accomplished through various processes (Rezaei-Zadeh \& Darwish, 2016; Teece, 2016). The existing literature assumes absorptive capacity to be an unrealised capability, made visible explicitly through organisational routines and processes (Kump, Engelmann, Kessler, \& Schweiger, 2019). This study views a target firm's organisational routines and processes as a reflection of the firm's productivity because productivity is a measure used to understand how a firm creates value through operational and organisational efficiencies (Bertrand \& Capron, 2015).

Effective knowledge transfer to target firms can generate value for those firms provided operational and organisational efficiencies are in place (Stiebale \& Vencappa, 2018). Organisational characteristics, such as structures, policies, routines and accumulated knowledge, have been reported to positively influence the building of knowledge within firms (Rezaei-Zadeh \& Darwish, 2016; Volberda et al., 2010) and influence firms' absorptive capacity. Moreover, organisational infrastructure and capacity, as well as the configuration of organisational routines and processes, affect the efficiency and effectiveness of knowledge utilisation (Lichtenthaler, 2016). It is not surprising, then, that the literature portrays absorptive capacity as a multidimensional construct (Hurtado-Ayala \& Gonzalez-Campo, 2015).

This article argues that productivity is a factor contributing to enhanced absorptive capacity, which supports the acquisition process (Schiffbauer et al., 2017). A firm's operating and implementation processes, it is argued, have a positive influence on absorptive capacity as they form a fundamental, internal framework that supports the introduction, integration and assimilation of knowledge into the firm. Lichtenthaler (2016) cautioned, however, that absorptive capacity can have negative consequences for a firm if the latter lacks the ability to satisfactorily transform the knowledge.

Deng (2010) found that absorptive capacity was an important determinant of Chinese acquiring firms' ability to obtain strategic assets and achieve superior business performance through productive operations and systems. These operations and systems paved the way for new knowledge to be introduced and integrated into the firms. This resonates with the view expressed by Cohen and Levinthal (1990), Agarwal, Milner and Riaño (2014) and Vaara, Sarala, Stahl and Bjorkman (2012) that a target firm's ability to introduce, integrate and assimilate new ideas depends on the extent of its absorptive capacity.

The results of empirical work carried out by Grigorieva and Petrunina (2015) illustrated that a target firm's postacquisition performance is heavily dependent on its preacquisition performance. Essentially, a firm lacking in operational and organisational efficiencies before the acquisition may not improve afterwards. However, Cassiman, Colombo, Garrone and Veugelers (2005) argued that acquisitions improve the potential to introduce new operations in pursuit of greater scope and economies of scale, thereby enhancing productivity. In contrast, Bernad et al. (2010) showed that following an acquisition, productivity improvements can be found in only half of the target firms. 
Stiebale and Vencappa (2018) while analysing the effects of domestic and international acquisitions on various outcomes in target firms, observed that acquisitions induce productivity gains through complementary knowledge transfer or the efficient reallocation of resources. However, contradictory research findings point to productivity not necessarily being enhanced following an acquisition (Bernad et al., 2010; Cummins \& Xie, 2008). Therefore, this article argues that productivity should not only be considered to be a result of successful acquisitions but also a factor contributing to the enhancement of absorptive capacity, which supports the acquisition process (Schiffbauer et al., 2017). The literature shows that this topic has not been investigated in the context of target firms - this despite it having strong business relevance (Miozzo, Desyllas, Lee, \& Miles, 2016).

Target firms must have the capability of reorganising resources to ensure efficiency gains. This is done by reallocating production across firms, leveraging economies of scale and economies of scope (Chen et al., 2017; Junni \& Sarala, 2013). Target firms that effectively interact with stakeholders see the benefit in terms of higher productivity. Such stakeholders include local suppliers, buyers, competitors, trade associations and the local labour market (Oldford \& Otchere, 2016). Target firms need to capture value by ensuring that they can respond to the need to restructure stakeholders or assets and/or redeploy resources (Mukherji et al., 2013; Yahiaoui et al., 2016). Effectively designed operations enhance target firms' productivity (Osabutey et al., 2014).

As such, it is hypothesised that if a target firm has productive operations and processes, its absorptive capacity is enhanced because value is generated through the effective use of acquired resources. We present the following hypotheses:

H1: A target firm with knowledge flow has enhanced absorptive capacity

H2: A target firm's productivity influences its absorptive capacity.

\section{Methodology}

The analysis was performed on data collected from 110 respondents in acquisitions published in the Competition Commission of South Africa's database. These data lists are available to the public online, in accordance with governmental regulations.

Emerging markets are characterised by underdeveloped institutional frameworks, which impact complex transactions such as M\&A (Lin et al., 2009), and therefore also FDI. The use of M\&A as a mode of entry into a market is reflected in FDI (Sabir, Rafique, \& Abbas, 2019). The institutional frameworks in these countries reflect government effectiveness, political stability, regulatory quality and the rule of law (Lin et al., 2009; Liou \& Rao-Nicholson, 2019; Lundqvist, Liljeblom, Loflund, \& Maury, 2019; Xie et al., 2017).

In defining South Africa as an EM, we rely on scoring in these dimensions against the developed-country metrics of the United States of America (Lin et al., 2009) and a further comparsion with the emerging economies of Brazil and India (Deng \& Yeng, 2015). We rely in turn on the World Bank's Worldwide Governance indicators from 2018 for the scores, across the various dimensions. Kraay, Kaufmann and Mastruzzi (2010) reported that the scores range from -2.5 to +2.5 , with scores in the range -2.5 to 0.0 being 'bad' and those above 0.0 being 'good'.

In comparison with the United States of America, South Africa - similar to India and Brazil - reflects markedly lower scores across all the dimensions (see Table 1).

The population for this study comprised all target firms within emerging economies. Lebedev et al. (2015), Nicholson and Salaber (2013) and Xie et al. (2017) supported the fact that acquisition studies apply the following set criteria: (1) the acquisition must be completed, (2) the acquisition has officially been announced (3) the target firm must be located in an emerging economy and (4) the acquisition must have occurred within a specified time period. The time period selected, 2015-2017, allowed recent acquisitions, currently in their post-acquisition phase, to be analysed (Morgan, 2017).

This study was largely based on research performed by Junni and Salara (2013), whose data set consisted of 123 respondents and measured the relationship between absorptive capacity and knowledge transfer in the acquiring and target firms. The final sample generated 110 completed questionnaires, which is in line with similar studies. As the M\&A were at the firm level, the respondents were deemed proxies of the firm (Ferreira et al., 2014).

\section{Measuring instrument}

Questionnaires measured respondents' answers on a Likert scale, ranging from 1 ('strongly disagree') to 5 ('strongly agree') (Flatten, Engelen, Zahra, \& Brettel, 2011). A questionnaire (see Appendix 1) was prepared in line with the literature to measure absorptive capacity, knowledge flow and productivity (Hurtado-Ayala \& Gonzalez-Campo, 2015; Mahnke, Pedersen, \& Verzin, 2005; Yang \& Rui, 2009). Consolidated data were analysed using IBM $^{\circledast}$ SPSS version 24. Prior to testing the existence and strength of the relationships amongst the constructs, the contructs' reliability and validity were first established.

TABLE 1: Emerging economy indicators of South Africa, Brazil and India in comparison with the United States of America.

\begin{tabular}{lcccc}
\hline Variable & South Africa & Brazil & India & $\begin{array}{c}\text { United States } \\
\text { of America }\end{array}$ \\
\hline Government effectiveness & 0.3 & -0.4 & 0.3 & 1.6 \\
Political stability & -0.2 & -0.4 & -1.0 & 0.5 \\
Regulatory quality & 0.1 & -0.3 & 0.0 & 1.6 \\
Rule of law & -0.1 & -0.3 & 0.0 & 1.5 \\
\hline
\end{tabular}

Source: Kaufman, D., Kraay, A., \& Mastruzzi, M. (2010). The worldwide governance indicators: Methodology and analytical issues (Policy Research Working Paper no. 5430). The World Methodology and analytical issues (Policy Research Working Paper no. 5430). The World
Bank Development Research Group, Retrieved from https://openknowledge.worldbank.org/ bitstream/handle/10986/3913/WPS5430.pdf?sequence $=1$ 


\section{Absorptive capacity}

Absorptive capacity was measured by asking questions about the introduction of new knowledge into the target firm (Yao et al., 2013), the integration of new and old knowledge and the assimilation of knowledge (Flatten et al., 2011; Zahra \& George, 2002). A broad range of functions was used to support the analysis of knowledge flow throughout the organisation as it helped to limit biases between functions and ensure that the organisation was holistically represented (Bernad et al., 2010).

\section{Knowledge flow}

Knowledge flow was measured by asking questions about how communication (Junni \& Sarala, 2013), processes (Teece, 2016) and skills (Sarala et al., 2016) facilitated knowledge flow into the firm (Hurtado-Ayala \& Gonzalez-Campo, 2015).

\section{Productivity}

Productivity was measured by asking questions about barriers to organisational structure, barriers to operational effectiveness and barriers to communicating during the integration process and implementing changes in order to enhance value (Oldford \& Otchere, 2016; Yang \& Rui, 2009).

\section{Descriptive variables}

The assessed sample set comprised various industries and firm sizes. As seen in research by $\mathrm{Li}$ et al. (2016), size, experience and industry specifics are examples of factors influencing acquisitions, and so these variables were included in the study's questionnaire. The questions related to number of subordinates, size of the firm, age of the firm, experience of the firm in dealing with acquisitions and relatedness/ involvement in the acquisition.

\section{Ethical considerations}

This article followed all ethical standards for research. Ethical clearance for the study was obtained from University of Pretoria's Gordon Institute of Business Science Research Ethics Committee.

\section{Results}

\section{Factor analysis and internal reliability}

Absorptive capacity, knowledge flow and productivity contained Kaiser-Meyer-Olkin (KMO) and Bartlett's test values of $p<0.05$ and $\mathrm{KMO}>0.7$ (Table 2 ). The overall KMO

\begin{tabular}{lccc} 
TABLE 2: Internal reliability and factor analysis results. & $\begin{array}{c}\text { Absorptive } \\
\text { capacity }\end{array}$ & $\begin{array}{c}\text { Knowledge } \\
\text { flow }\end{array}$ & Productivity \\
\hline Sample size & 110 & 110 & 110 \\
Number of items & 10 & 10 & 10 \\
Cronbach's alpha & 0.80 & 0.84 & 0.87 \\
KMO measure of sampling adequacy & 0.76 & 0.78 & 0.80 \\
Bartlett's test of sphericity $\rho$ & 0.00 & 0.00 & 0.00 \\
Percentage of variance extracted & 63.34 & 70.32 & 70.89 \\
$\begin{array}{l}\text { Number of factors extracted } \\
\text { (eigenvalue } \geq 1 \text { ) }\end{array}$ & 3 & 3 & 3 \\
\hline
\end{tabular}

sampling adequacy was middling at 0.760 , with 0.775 and 0.802 for absorptive capacity, knowledge flow and productivity, accordingly. With significant scores in the Bartlett's tests for sphericity at $\rho=0.00$, this indicated that the data were factorisable and were therefore deemed suitable for principal component analysis (PCA).

The Exploratory Factor Analysis (EFA) analysis showed eigenvalues $>1$ for all constructs tested with percentage extractions $>63 \%$. To reflect further on the results, the Cronbach's alpha of absorptive capacity indicated reliability ( $\alpha=0.804$ ) of the questions used to test for the construct. We found that the absorptive capacity of the target firm consisted of three variables that were deemed underlying factors. The factors were classified in accordance with the focus of the questions: introduction of knowledge, integration of knowledge and assimilation of knowledge, respectively. As seen in Table 3, the total percentage of variance explained by these extracted factors was $63 \%$. Similarly, knowledge flow consisted of three factors: communication, skills required and processes that support knowledge flow.

The total percentage of variance explained by these extracted factors was noted at $70 \%$ and therefore the factor was deemed suitable. Lastly, productivity consisted of two factors: implementation of processes and efficient operational processes. The total percentage of variance explained by these extracted factors was also observed at $59 \%$.

Confirmatory factor analysis was used to verify the convergent and discriminant validity of the measurement model. The comparative fit index (CFI $\leq 0.09)$ and the incremental fit index (IFI) indicated that the model did not have a good fit. Similarly, the root mean square that was identified (RMSEA > 0.08) for all constructs indicated that there was not a good fit (Johnson \& Christensen, 2014); however, these results may be because of the sample size (Hair, Black, Babin, \& Anderson, 2010; Izquierdo, Olea, \& Abad, 2014; Johnson \& Christensen, 2014).

A correlation analysis was performed to determine the convergent or bivariate relationship between the variables extracted through the EFA. Strong and positive correlations indicated evidence of convergent validity of the variables. All factors showed convergent validity and therefore could be considered statistically significant for moderate relationships existing between the constructs (see Table 4).

TABLE 3: Percentage extraction of subfactors.

\begin{tabular}{llc}
\hline Variable & Category & Extraction (\%) \\
\hline Absorptive capacity & Introduction of knowledge & 37.5 \\
& Integration of knowledge & 52.3 \\
& Assimilation of knowledge & 63.3 \\
Knowledge flow & Communication & 40.9 \\
& Processes & 57.7 \\
\multirow{2}{*}{ Productivity } & Skill & 70.3 \\
& Implementation of processes & 46.0 \\
& Operational processes & 59.8 \\
\hline
\end{tabular}


TABLE 4: Descriptive statistics for constructs and correlation.

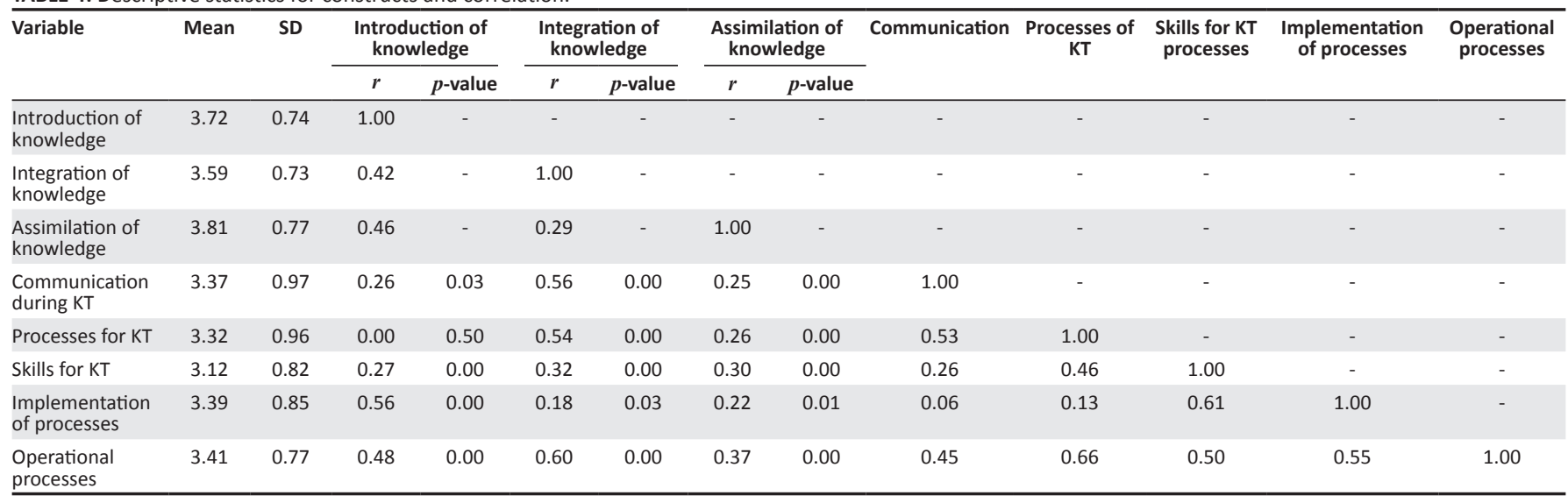

$\mathrm{SD}$, standard deviation; $\mathrm{KT}$, knowledge transfer.

TABLE 5: Linear regression data.

\begin{tabular}{|c|c|c|c|c|c|c|}
\hline \multirow[t]{2}{*}{ Variable } & \multicolumn{2}{|c|}{ Introduction of knowledge } & \multicolumn{2}{|c|}{ Integration of knowledge } & \multicolumn{2}{|c|}{ Assimilation of knowledge } \\
\hline & $\beta$ & $R^{2}$ & $\beta$ & $R^{2}$ & $\beta$ & $R^{2}$ \\
\hline Communication during KT & 0.26 & $0.067^{*}$ & 0.56 & $0.314 *$ & 0.25 & $0.63 *$ \\
\hline Processes for KT & 0.00 & $0.000 *$ & 0.54 & $0.290 *$ & 0.26 & $0.70 *$ \\
\hline Skills for KT & 0.27 & $0.074 *$ & 0.10 & $0.100 *$ & 0.30 & $0.09 *$ \\
\hline Implementation of processes & 0.56 & $0.310^{*}$ & 0.18 & $0.030 *$ & 0.22 & $0.05 *$ \\
\hline Operational processes & 0.48 & $0.230 *$ & 0.60 & $0.360 *$ & 0.37 & $0.13^{*}$ \\
\hline
\end{tabular}

$*, R^{2}=\Delta \mathrm{R}$.

$\mathrm{KT}$, knowledge transfer.

\section{Correlations between constructs}

Introduction of knowledge showed a positive acceptable correlation in relation to communication required for knowledge flow $(\rho=0.26 ; p<0.05)$ and skills required for knowledge flow $(\rho=0.27 ; p<0.05)$. Processes for knowledge flow ( $\rho=0.00 ; p>0.05$ ) showed a $p>0.05$, indicating nonsignificance of this data point. Integration of knowledge also showed a positive relation to communication of knowledge transfers $(\rho=0.56 ; p<0.05)$, processes for knowledge transfers $(\rho=0.54 ; p<0.05)$ and skills involved in knowledge transfers $(\rho=0.36 ; p<0.05)$. These strong correlation values showed equally significant, positive, linear regression values. This indicates the importance of knowledge integration into the target firm. Integration of knowledge transferred requires knowledge to have effective communication, processes and skills, as shown in the linear correlation seen in the data obtained from respondents. Assimilation of knowledge was positively related to communication during knowledge transfer $(\rho=0.25 ; p<0.05)$, processes for knowledge transfer $(\rho=0.26 ; p<0.05)$ and skills required in knowledge transfer $(\rho=0.30 ; p<0.05)$.

Therefore, Hypothesis 1 was supported ( $\rho=0.27 ; p<0.05)$, showing that target firms possessing a good flow of knowledge via effective communication, processes and skills will enhance the targets firms' absorptive capacity.

All regression values (Table 5) were positive, therefore indicating a linear positive relationship between absorptive capacity and knowledge flow. The strongest and most significant relationship was between processes involved in knowledge flow and assimilation of knowledge. This relationship indicated that a change in processes of knowledge flow will explain $70 \%$ of the change in the assimilation of acquired knowledge.

In relation to Hypothesis 2, prior studies investigated the productivity of firms following an acquisition. However, this research observed the variable in terms of the relationship with absorptive capacity, with a specific focus on the target firm (Oldford \& Otchere, 2016). Strong positive correlations were found for each of the research constructs. The introduction of knowledge and implementation of processes $(\rho=0.56$; $p<0.05)$ and operational processes $(\rho=0.48 ; p<0.05)$ showed a strong correlation, pointing to a relationship between these variables. Integration of knowledge showed a moderate relationship with implementation of processes $(\rho=0.18$; $p<0.05)$, with a strong correlation to operational processes $(\rho=0.60 ; p<0.00)$. Assimilation of knowledge consisted of positive moderate correlations with implementation of processes $(\rho=0.22 ; p<0.05)$ and a similarly moderate correlation with operational processes ( $\rho=0.37$; $p<0.05)$. Higher correlations were expected for the relationship between assimilation of knowledge and operational processes, as research shows evidence of a strong correlation and dependence between these variables (Teece, 2016).

The overall correlation between the absorptive capacity variables and the productivity variables were moderate but significant, indicating that productivity is not only related to the behaviour of a firm after an acquisition but also influences absorptive capacity during an acquisition. The $\mathrm{R}^{2}$ values were noticed as $>0.05$; therefore, the positive linear regression was a good fit. The most significant relationship was that 
between processes involved in effective operational processes and integration of knowledge. This relationship showed that a change in effective operational processes can explain $36 \%$ of the change in the integration of knowledge.

\section{Conclusion}

These results contribute to the M\&A literature on absorptive capacity by presenting key findings on the absorptive capacity of target firms in EM. In particular, this study illustrates the importance of knowledge flow and productivity on a target firm's absorptive capacity to extract the required value from acquired knowledge and to effectively implement it. This finding is supported by research performed by Du and Sim (2016) who showed that specific characteristics relating to the target firm influence acquisition performance.

This study provides a new perspective on target firms as the findings relate to a population sample consisting of EM target firms (Du \& Sim, 2016; Grigorieva \& Petrunina, 2015). The literature has revealed a need to understand the absorptive capacity in EM target firms because of an over-concentration of DM literature on the subject, which overlooks the influence of absorptive capacity in target firms in acquisition cases (Grigorieva \& Petrunina, 2015; Junni \& Sarala, 2013; Nair et al., 2016). As EM target firms tend to face contextual challenges, they must have an effective absorptive capacity for knowledge because the utilisation of acquired resources supports performance.

Within the EM context, the aim of this study was to determine the influence of knowledge flow and productivity on the enhancement of absorptive capacity in target firms. Our findings illustrate that knowledge flow and productivity within target firms have positive correlations with the firms' absorptive capacity. This indicates that the successful movement of knowledge within the firm together with conducive operational processes will support the introduction and integration of external knowledge into the target firms and the assimilation of this knowledge. This, in turn, supports the aim of realising the strategic intent of the acquisition (Du \& Boateng, 2012).

These findings show a link between operational knowledge flow, via effective communication and processes and focused dimensions of absorptive capacity - specifically integration and assimilation of knowledge. Studies have largely failed to analyse absorptive capacity as a multilayered construct, choosing instead to see it as a one-dimensional construct (Hurtado-Ayala \& Gonzalez-Campo, 2015). The introduction of knowledge into the target firm, the integration of new and old knowledge and the assimilation of this knowledge have varying influences on each dimension. This study empirically shows that this aspect must be taken into consideration when analysing a target firm's absorptive capacity. This is because knowledge flow specifically influences the integration and assimilation of knowledge resources, while productivity within a target firm influences the introduction and integration of knowledge.
Our results indicate that knowledge flow within EM target firms positively influences a firm's absorptive capacity. Our results are in line with research by Mahnke et al. (2005) who showed empirically that absorptive capacity has a strong, positive impact on the flow of knowledge within a firm, resulting in a strong, positive impact on business performance. This is a significant finding that points to the need for EM target firms, which are seeking to leverage their absorptive capacity to positively impact M\&A, to ensure that there is a good flow of knowledge both to the firm and within the firm (Martín-de Castro, 2015).

Communication of knowledge into the firm and processes by which the knowledge is encouraged to flow showed a stronger influence on absorptive capacity integration and assimilation of knowledge. This indicates that firms must ensure that newly acquired knowledge is communicated into the firm and that employees are allowed to absorb the knowledge with a view to strengthening business performance. Communication of newly acquired knowledge will also lead not only through sharing of the knowledge, to the development of social ties and connectedness between the employees but also between the acquiring and target firm. This strengthens the acquiring-target relationship (Junni \& Sarala, 2013).

The study's results also highlight the significance of a knowledge-processing system in the target firm, based on extensive communication and teamwork. This supports acquisition research which holds that communication during integration processes influences absorptive capacity (Junni \& Sarala, 2013). It is pertinent for firms to supplement the seamless integration of resources with processes that facilitate the flow of knowledge (Khan et al., 2017; Yang \& Rui, 2009). This emphasises the importance of management actions to ensure that the target firm can effectively communicate the new knowledge internally. Managers must ensure that the required processes are present in the target firm to support the integration of new and old knowledge. This allows a firm to consolidate and review the relevance of the knowledge available. This review allows the target firm to better understand the requirements and implications of the acquired knowledge and where it fits into the overall vision.

Processes supporting knowledge flow within target firms and those promoting the assimilation of knowledge on the basis of absorptive capacity showed a significant relationship, indicating that a change in processes driving knowledge flow explains $70 \%$ of the resulting change in the assimilation of knowledge. This has significant business implications as target firms that have adequate processes in place can effectively assimilate their knowledge and in the process improve their knowledge resources to their commercial advantage. Tzokas, Kim, Akbar and Al-Dajani (2015) emphasised that assimilated knowledge drives innovative ideas, which in turn enhance business performance. Research has shown that knowledge flow is seen to be facilitated by managers within a target firm, and it is managers' experience 
that defines the processes and plans for integrating and assimilating knowledge into the firm. However, as shown in this study's results, firms must ensure that managers have the requisite skills, and they are supported by the necessary processes, if they are to effectively organise and utilise the knowledge (Rezaei-Zadeh \& Darwish, 2016).

The findings highlight the importance of effective absorptive capacity in emerging economies, which are seeking to stimulate growth and development from the new knowledge accompanying the acquisition process. The literature suggests that emerging economies have weak knowledge transfer capabilities. Thus, this study's findings suggest that absorptive capacity can improve the prospects of effective knowledge transfer. Target firms with the absorptive capability to assimilate new knowledge for commercial benefit should capitalise on the full value of resources attained through the acquisition to achieve the desired growth.

Regarding Hypothesis 2, this study confirms that productivity is not necessarily an outcome of an acquisition; it is, in fact, a strong influence on the devleopment of absorptive capacity and the integration of knowledge into the firm. Foreign investors set out to acquire the bestperforming firms with productivity advantages as these firms are able to effectively introduce and integrate knowledge, thereby sustaining the performance of the acquisition (Bernad et al., 2010; Cummins \& Xie, 2008). This study contributes to the M\&A literature by emphasising that the introduction and integration of acquired knowledge into a firm requires the effective implementation of new processes and sound operational processes. This will allow knowledge to smoothly feed into the target firm's internal systems and allows for the integration of internal and external knowledge resources (Najafi-Tavani et al., 2018). As the level of absorptive capacity increases, a target firm will become more capable of learning from its local environment and leveraging local capabilities to integrate knowledge assets. According to these results, target firms with sound implementation processes and well-functioning day-to-day operations are more likely to successfully utilise new knowledge. In contrast to some studies that assert acquiring firms must take charge of ensuring knowledge flow as this will facilitate the transfer of the acquiring firm's best practices, this study illustrates that it is, in fact, also the operational processes within the target firm that will facilitate the introduction of acquired knowledge into the firm.

Another explanation for the relationship between productivity and the introduction and integration of knowledge is that operational processes act as a 'funnel or screening mechanism to productively utilise external knowledge' (Tzokas et al., 2015). This can be attributed to the absorptive capabilities of the target firm to extract value from a firm's resources. This indicates that productivity within the target firm creates a pathway for new knowledge to enter the firm and for operational processes to integrate the knowledge into the day-to-day operations. Enhancing the prospects of a successful acquisition is evident in the literature, which shows that target firms are acquired specifically for a particular capability or their general performance level as such firms are better placed to manage the knowledge acquisition process flowing from the acquisition.

These results indicate that productivity enhances the absorptive capacity of target firms, thereby facilitating the introduction and integration of acquired knowledge into new processes or products. Acquired knowledge, if well integrated, can be reviewed to look for any synergies with the target firm's current resources, which can be leveraged to create additional value. This study shows that firms with well-constructed implementation processes will have higher absorptive capacity, which can allow knowledge to be internalised more efficiently (Martín-de Castro, 2015).

Finally, the study has highlighted the importance of resources as unique assets that are crucial for implementing valuecreating strategies. Ahammad et al. (2016) and Bertrand and Capron (2015) stated that the use of knowledge, skills and resources is a significant feature of absorptive capacity, which is key to the success and sustainability of an acquisition.

The results of this study indicate that to optimise acquired knowledge resources, target firms must ensure that these resources are communicated into the firm, using the correct processes and skills. Knowledge flow will have a positive impact on the firm's absorptive capacity as it will stimulate the integration of the acquired knowledge and ensure that it translates into value. Furthermore, productivity in the firm will rise with the help of efficient implementation and operational processes.

It should be observed that only target firms from Southern Africa were included in the study. Therefore, future research should validate these findings with a larger sample of foreign acquisitions. This will contribute to the M\&A literature because some acquisitions will undergo significant changes while others will experience minimal changes, depending on location and strategic intent. Future research could apply a longitudinal method to examine how absorptive capacity and knowledge flow and productivity change over a period of time.

This study was deliberately biased towards the perspective of the target firm. Further research should build on this study and include the perspectives of acquiring firms. This will allow a comparison to be made between the two entities, which will either strengthen or weaken the argument regarding the different factors influencing target firms and acquiring firms, respectively. Lastly, this study was also limited to an analysis of the effects of productivity and knowledge flow on absorptive capacity. Yet there are other variables that can create or destroy absorptive capacity, which deserve research attention. 


\section{Acknowledgements Competing interests}

The authors declare that they have no financial or personal relationships that may have inappropriately influenced them in writing this article.

\section{Authors' contributions}

S.P., M.D.C., A.V. and M.M. contributed equally to this work.

\section{Funding information}

The authors received no financial support for the research, authorship and/or publication of this article.

\section{Data availability}

Raw data of this study are available from the corresponding author, M.D.C., upon reasonable request.

\section{Disclaimer}

The views and opinions expressed in this article are those of the authors and do not necessarily reflect the official policy or position of any affiliated agency of the authors.

\section{References}

Acemoglu, D., \& Johnson, S. (2005). Unbundling institutions. Journal of political Economy, 113(5), 949-995.

Agarwal, N., Milner, C., \& Riaño, A. (2014). Credit constraints and spillovers from foreign firms in China. Journal of Banking \& Finance, 48, 261-275.

Ahammad, M.F., Tarba, S.Y., Liu, Y., \& Glaister, K.W. (2016). Knowledge transfer and cross-border acquisition performance: The impact of cultural distance and employee retention. International Business Review, 25(1), 66-75. https://doi. org/10.1016/j.ibusrev.2014.06.015

Andersson, U., Dasí, Á., Mudambi, R., \& Pedersen, T. (2016). Technology, innovation and knowledge: The importance of ideas and international connectivity. Journal of World Business, 51(1), 153-162.

Bauer, F., Matzler, K., \& Wolf, S. (2016). M\&A and innovation: The role of integration and cultural differences - A central European targets perspective. International Business Review, 25(1), 76-86. https://doi.org/10.1016/j.ibusrev.2014.07.010

Bernad, C., Fuentelsaz, L., \& Gómez, J. (2010). The effect of mergers and acquisitions on productivity: An empirical application to Spanish banking. Omega (United Kingdom), 38(5), 283-293. https://doi.org/10.1016/j.omega.2009.07.005

Bertrand, O., \& Capron, L. (2015). Productivity enhancement at home via cross-border acquisitions: The roles of learning and contemporaneous domestic investments. Strategic Management Journal, 36(5), 640-658. https://doi.org/10.1002/ smj.2256

Buckley, P.J., Munjal, S., Enderwick, P., \& Forsans, N. (2016). Do foreign resources assist or impede internationalisation? Evidence from internationalisation of Indian multinational enterprises. International Business Review, 25(1), 130-140. https://doi.org/10.1016/j.ibusrev.2015.04.004

Capron, L., Mitchell, W., \& Swaminathan, A. (2001). Asset divestiture following horizontal acquisitions: A dynamic view. Strategic Management Journal, 22(9), 817-844. https://doi.org/10.1002/smj.175

Cassiman, B., Colombo, M.G., Garrone, P., \& Veugelers, R. (2005). The impact of M\&A on the R\&D process: An empirical analysis of the role of technological-and marketrelatedness. Research Policy, 34(2), 195-220.

Chen, Y., Hua, X., \& Boateng, A. (2017). Effects of foreign acquisitions on financial constraints, productivity and investment in R\&D of target firms in China. International Business Review, 26(4), 640-651. https://doi.org/10.1016/j. ibusrev.2016.12.005

Cohen, W.M., \& Levinthal, D.A. (1990). Absorptive capacity: A new perspective on learning and innovation. Administrative Science Quarterly, 35(1), 128-152. https://doi.org/10.2307/2393553

Çömez-Dolgan, N., \& Tanyeri, B. (2015). Inventory performance with pooling: Evidence from mergers and acquisitions. International Journal of Production Economics, 168, 331-339. https://doi.org/10.1016/j.ijpe.2015.06.003

Cummins, J.D., \& Xie, X. (2008). Mergers and acquisitions in the US property-liability insurance industry: Productivity and efficiency effects. Journal of Banking and Finance, 32(1), 30-55. https://doi.org/10.1016/j.jbankfin.2007.09.003
Deng, P. (2010). What determines performance of cross-border M\&As by Chinese companies? An absorptive capacity perspective. Thunderbird International Business Review, 52(6), 509-524

Deng, P., \& Yang, M. (2015). Cross-border mergers and acquisitions by emerging market firms: A comparative investigation. International Business Review, 24(1), 157-172. https://doi.org/10.1016/j.ibusrev.2014.07.005

Department of Higher Education and Training. (2019). Skills supply and demand in South Africa. Pretoria: Author.

Di Stefano, G., Peteraf, M., \& Verona, G. (2014). The organizational drivetrain: A road to integration of dynamic capabilities research. Academy of Management Perspectives, 28(4), 307-327. https://doi.org/10.5465/amp.2013.0100

Du, K., \& Sim, N. (2016). Mergers, acquisitions, and bank efficiency: Cross-country evidence from emerging markets. Research in International Business and Finance, 36, 499-510. https://doi.org/10.1016/j.ribaf.2015.10.005

Du, M., \& Boateng, A. (2012). Cross-border mergers \& acquisitions by emerging market firms: A review and future direction. Journal of Entrepreneurship Perspectives, 1(2), 24-54.

Estrin, S., \& Prevezer, M. (2011). The role of informal institutions in corporate governance: Brazil, Russia, India, and China compared. Asia Pacific journal of management, 28(1), 41-67.

Ferreira, M.P., Santos, J.C., De Almeida, M.I.R., \& Reis, N.R. (2014). Mergers \& acquisitions research: A bibliometric study of top strategy and international business journals, 1980-2010. Journal of Business Research, 67(12), 2550-2558. https://doi.org/10.1016/j.jbusres.2014.03.015

Flatten, T.C., Engelen, A., Zahra, S.A., \& Brettel, M. (2011). A measure of absorptive capacity: Scale development and validation. European Management Journal, 29(2), 98-116. https://doi.org/10.1016/j.emj.2010.11.002

Grigorieva, S., \& Petrunina, T. (2015). The performance of mergers and acquisitions in emerging capital markets: New angle. Journal of Management Control, 26(4), 377-403. https://doi.org/10.1007/s00187-015-0219-9

Hair, J.F., Black, W.C., Babin, B.J., \& Anderson, R.E. (2010). Multivariate data analysis Global edition. Upper Saddle River, NJ: Pearson Education Limited.

Hamel, G., \& Prah, C.K. (1994). Competing for the future - Breakthrough strategies for seizing control of your industry and creating the markets of tomorrow. Boston, MA: Harvard Business School Press.

Helfat, C.E., \& Peteraf, M.A. (2014). Managerial cognitive capabilities and the microfoundations of dynamic capabilities. Strategic Management Journal, 36(6), 831-850. https://doi.org/10.1002/smj.2247

Hurtado-Ayala, A., \& Gonzalez-Campo, C.H. (2015). Measurement of knowledge absorptive capacity: An estimated indicator for the manufacturing and service sector in Colombia. Revista Journal, 9(2), 16-42. https://doi.org/10.3232/ GCG.2015.V9.N2.01

Izquierdo, I., Olea, J., \& Abad, F. (2014). Exploratory factor analysis in validation studies: Uses and recommendations. Psicothema, 26(3), 395-400. https://doi. org/10.7334/psicothema2013.349

Johnson, B.R., \& Christensen, L. (2014). Preparing to teach diverse student populations: A British and American perspective. Educational Research, 39(3), 342-350. https://doi.org/10.1080/0013188970390309

Junni, P., \& Sarala, R.M. (2013). The role of absorptive capacity in acquisition knowledge transfer. Thunderbird International Business Review, 55(4), 419-438. https://doi.org/10.1002/tie.21554/full

Kaufman, D., Kraay, A., \& Mastruzzi, M. (2010). The worldwide governance indicators: Methodology and analytical issues (Policy Research Working Paper no. 5430). The World Bank Development Research Group, Retrieved from https:// openknowledge.worldbank.org/bitstream/handle/10986/3913/WPS5430. pdf?sequence $=1$

Khan, Z., Rao-Nicholson, R., Akhtar, P., \& He, S. (2017). Cross-border mergers and acquisitions of emerging economies' multinational enterprises - The mediating role of socialization integration mechanisms for successful integration. Human Resource Management Review. Retrieved from https://doi.org/10.1016/j. hrmr.2016.12.003

Kump, B., Engelmann, A., Kessler, A., \& Schweiger, C. (2019). Toward a dynamic capabilities scale: Measuring organizational sensing, seizing, and transforming capacities. Industrial and Corporate Change, 28(5), 1149-1172. https://doi. org/10.1093/icc/dty054

Lane, P.J., \& Lubatkin, M. (1998). Relative absorptive capacity and interorganizational learning. Strategic Management Journal, 19(5), 461-477.

Lebedev, S., Peng, M.W., Xie, E., \& Stevens, C.E. (2015). Mergers and acquisitions in and out of emerging economies. Journal of World Business, 50(4), 651-662. https://doi.org/10.1016/j.jwb.2014.09.003

Li, J., Li, P., \& Wang, B. (2016). Do cross-border acquisitions create value? Evidence from overseas acquisitions by Chinese firms. International Business Review, 25(2), 471-483. https://doi.org/10.1016/j.ibusrev.2015.08.003

Lichtenthaler, U. (2016). Absorptive capacity and firm performance: An integrative framework of benefits and downsides. Technology Analysis and Strategic Management, 28(6), 664-676. https://doi.org/10.1080/09537325.2015.1131258

Lin, Z., Peng, M.W., Yang, H., \& Sun, S.L. (2009). How do networks and learning drive M\&As? An institutional comparison between China and the United States. Strategic Management Journal, 30(10), 1113-1132. https://doi.org/10.1002/ smj.777

Liou, R.S., \& Rao-Nicholson, R. (2019). Age matters: The contingency of economic distance and economic freedom in emerging market firms' cross-border M\&A performance. Management International Review, 59(3), 355-386. https://doi. org/10.1007/s11575-019-00381-y 
Liu, X., Gao, L., Lu, J., \& Lioliou, E. (2016). Does learning at home and from abroad boost the foreign subsidiary performance of emerging economy multinational enterprises? International Business Review, 25(1) 141-151. https://doi. org/10.1016/j.ibusrev.2014.10.012

Lundqvist, A., Liljeblom, E., Löflund, A., \& Maury, B. (2019). M\&As in Africa - Effects of law and governance. International Journal of Emerging Markets, 14(5), 873-898. https://doi.org/10.1108/JOEM-05-2018-0223

Martín-de Castro, G. (2015). Knowledge management and innovation in knowledgebased and high-tech industrial markets: The role of openness and absorptive capacity. Industrial Marketing Management, 47, 143-146. https://doi. org/10.1016/j.indmarman.2015.02.032

Miozzo, M., Desyllas, P., Lee, H.F., \& Miles, I. (2016). Innovation collaboration and appropriability by knowledge-intensive business services firms. Research Policy, 45(7), 1337-1351.

Mahnke, V., Pedersen, T., \& Venzin, M. (2005). Why do MNC subsidiaries engage in knowledge sharing with other subsidiaries and what are the implication for performance? Retrieved from https://www.researchgate.net/publication/ 254877796

Morgan, D.L. (2017). Integrating qualitative and quantitative methods: A pragmatic approach. Portland, OR: Sage.

Mukherji, A., Mukherji, J., Dibrell, C., \& Francis, J.D. (2013). Overbidding in crossborder acquisitions: Misperceptions in assessing and valuing knowledge. Journal of World Business, 48(1), 39-46. https://doi.org/10.1016/j.jwb.2012.06.005

Nair, S.R., Demirbag, M., \& Mellahi, K. (2016). Reverse knowledge transfer in emerging market multinationals: The Indian context. International Business Review, 25(1), 152-164. https://doi.org/10.1016/j.ibusrev.2015.02.011

Najafi-Tavani, Z., Robson, M.J., Zaefarian, G., Andersson, U., \& Yu, C. (2018). Building subsidiary local responsiveness: (When) does the directionality of intrafirm knowledge transfers matter? Journal of World Business, 53(4), 475-492. https:// doi.org/10.1016/j.jwb.2018.01.004

Nicholson, R.R., \& Salaber, J. (2013). The motives and performance of cross-borde acquirers from emerging economies: Comparison between Chinese and Indian firms. International Business Review, 22(6), 963-980. https://doi.org/10.1016/j. ibusrev.2013.02.003

Nielsen, A.P. (2006). Understanding dynamic capabilities through knowledge management. Journal of Knowledge Management, 10(4), 59-71. https://doi. org/10.1108/13673270610679363

Nienaber, H. (2007). Assessing the management status of South Africa. European Business Review, 19(1), 72. https://doi.org/10.1108/09555340710714153

Nieves, J., \& Haller, S. (2014). Building dynamic capabilities through knowledge resources. Tourism Management, 40, 224-232. https://doi.org/10.1016/j tourman.2013.06.010

Oldford, E., \& Otchere, I. (2016). Are cross-border acquisitions enemy of labor? An examination of employment and productivity effects. Pacific Basin Finance Journal, 40(2), 438-455. https://doi.org/10.1016/j.pacfin.2016.06.001

Osabutey, E.L.C., Williams, K., \& Debrah, Y.A. (2014). The potential for technology and knowledge transfers between foreign and local firms: A study of the construction industry in Ghana. Journal of World Business, 49(4), 560-571. https://doi. org/10.1016/j.jwb.2013.12.009

Radipere, S., \& Van Scheers, L. (2005). Investigating whether a lack of marketing and managerial skills is the main cause of business failure in South Africa: Management. South African Journal of Economic and Management Sciences, 8(4), 402-411. https://doi.org/10.4102/sajems.v8i4.1171

Rahman, M., \& Lambkin, M. (2015). Creating or destroying value through mergers and acquisitions: A marketing perspective. Industrial Marketing Management, 46, 24-35. https://doi.org/10.1016/j.indmarman.2015.01.003

Rezaei-Zadeh, M., \& Darwish, T.K. (2016). Antecedents of absorptive capacity: A new model for developing learning processes. The Learning Organization, 23(1), 77-91. https://doi.org/10.1108/TLO-04-2015-0026

Sabir, S., Rafique, A., \& Abbas, K. (2019). Institutions and FDI: Evidence from developed and developing countries. Financial Innovation, 5(1), 8. https://doi.org/10.1186/ s40854-019-0123-7
Sarala, R.M., Junni, P., Cooper, C.L., \& Tarba, S.Y. (2016). A sociocultural perspective on knowledge transfer in mergers and acquisitions. Journal of Management, 42(5), 1230-1249. https://doi.org/10.1177/0149206314530167

Schiffbauer, M., Siedschlag, I., \& Ruane, F. (2017). Do foreign mergers and acquisitions boost firm productivity? International Business Review, 26(6), 1124-1140. https:// doi.org/10.1016/j.ibusrev.2017.04.003

Sears, J., \& Hoetker, G. (2014). Technological overlap, technological capabilities, and resource recombination in technological acquisitions. Strategic Management Journal, 35(1), 48-67. https://doi.org/10.1002/smj.2083

Stahl, B.G.K., Angwin, D.N., Very, P., Gomes, E., Weber, Y., Tarba, S.Y., ... Yildiz, H.E. (2013). Sociocultural integration in mergers and acquisitions: Unresolved paradoxes and directions for future research. Thunderbird International Business Review, 55(4) 333-356. https://doi.org/10.1002/tie.21549

Stiebale, J., \& Vencappa, D. (2018). Acquisitions, markups, efficiency, and product quality: Evidence from India. Journal of International Economics, 112(C), 70-87. https://doi.org/10.1016/j.jinteco.2018.02.005

Teece, D.J. (2007). Explicating dynamic capabilities: The nature and microfoundation of (sustainable) enterprise performance. Strategic Management Journal, 28(13) 1319-1350. https://doi.org/10.1002/smj.640

Teece, D.J. (2016). Dynamic capabilities and entrepreneurial management in large organizations: Toward a theory of the (entrepreneurial) firm. European Economic Review, 86, 202-216. https://doi.org/10.1016/j.euroecorev.2015.11.006

Tzokas, N., Kim, Y.A., Akbar, H., \& Al-Dajani, H. (2015). Absorptive capacity and performance: The role of customer relationship and technological capabilities in high-tech SMEs. Industrial Marketing Management, 47, 134-142. https://doi. org/10.1016/j.indmarman.2015.02.033

Vaara, E., Sarala, R., Stahl, G.K., \& Björkman, I. (2012). The impact of organizational and national cultural differences on social conflict and knowledge transfer in international acquisitions. Journal of Management Studies, 49(1), 1-27.

Volberda, H.W., Foss, N.J., \& Lyles, M.A. (2010). Absorbing the concept of absorptive capacity: How to realize its potential in the organization field. Organization Science, 21(4), 931-951. https://doi.org/10.1287/orsc.1090.0503

Wang, C.L., \& Ahmed, P. (2004). Leveraging knowledge in the innovation and learning process at GKN. International Journal of Technology Management, 27(6/7), 674-688. https://doi.org/10.1504/IJTM.2004.004909

Wang, C.L., \& Ahmed, P.K. (2007). Dynamic capabilities: A review and research agenda. International Journal of Management Reviews, 9(1), 31-51. https://doi. org/10.1111/j.1468-2370.2007.00201.x

Wang, J., \& Wang, X. (2015). Benefits of foreign ownership: Evidence from foreign direct investment in china. Journal of International Economics, 97(2), 325-338. https://doi.org/10.1016/j.jinteco.2015.07.006

Xie, E., Reddy, K.S., \& Liang, J. (2017). Country-specific determinants of cross-border mergers and acquisitions: A comprehensive review and future research directions. Journal of World Business, 52(2), 127-183. https://doi.org/10.1016/j. jwb.2016.12.005

Yahiaoui, D., Chebbi, H., \& Weber, Y. (2016). HR practices, context and knowledge transfer in M\&A. International Journal of Human Resource Management, 27(20), 2415-2435. https://doi.org/10.1080/09585192.2016.1226192

Yang, J., \& Rui, M. (2009). Turning knowledge into new product creativity: An empirical study. Industrial Management \& Data Systems, 109(9), 1197-1210. https://doi. org/10.1108/02635570911002270

Yao, Z., Yang, Z., Fisher, G., Ma, C., \& Fang, E. (2013). Knowledge complementtarity, knowledge absorption effectiveness, and new product performance: The exploration of international joint vebtures in China. International Business Review, 22(1), 216-227. https://doi.org/10.1016/j.ibusrev.2012.04.002

Zahra, S.A., \& George, G. (2002). Absorptive capacity: A review, reconceptualization and extension. Academy of Management Review, 27(2), 185-203. https://doi. org/10.5465/amr.2002.6587995

Zahra, S.A., Nielsen, A.P., \& Bogner, W.C. (1999). Corporate entrepreneurship knowledge, and competence development. Entrepreneurship Theory and Practice, 23(3), 169-189. https://doi.org/10.1177/104225879902300310 


\section{Appendix 1}

TABLE 1-A1: Questionnaire.

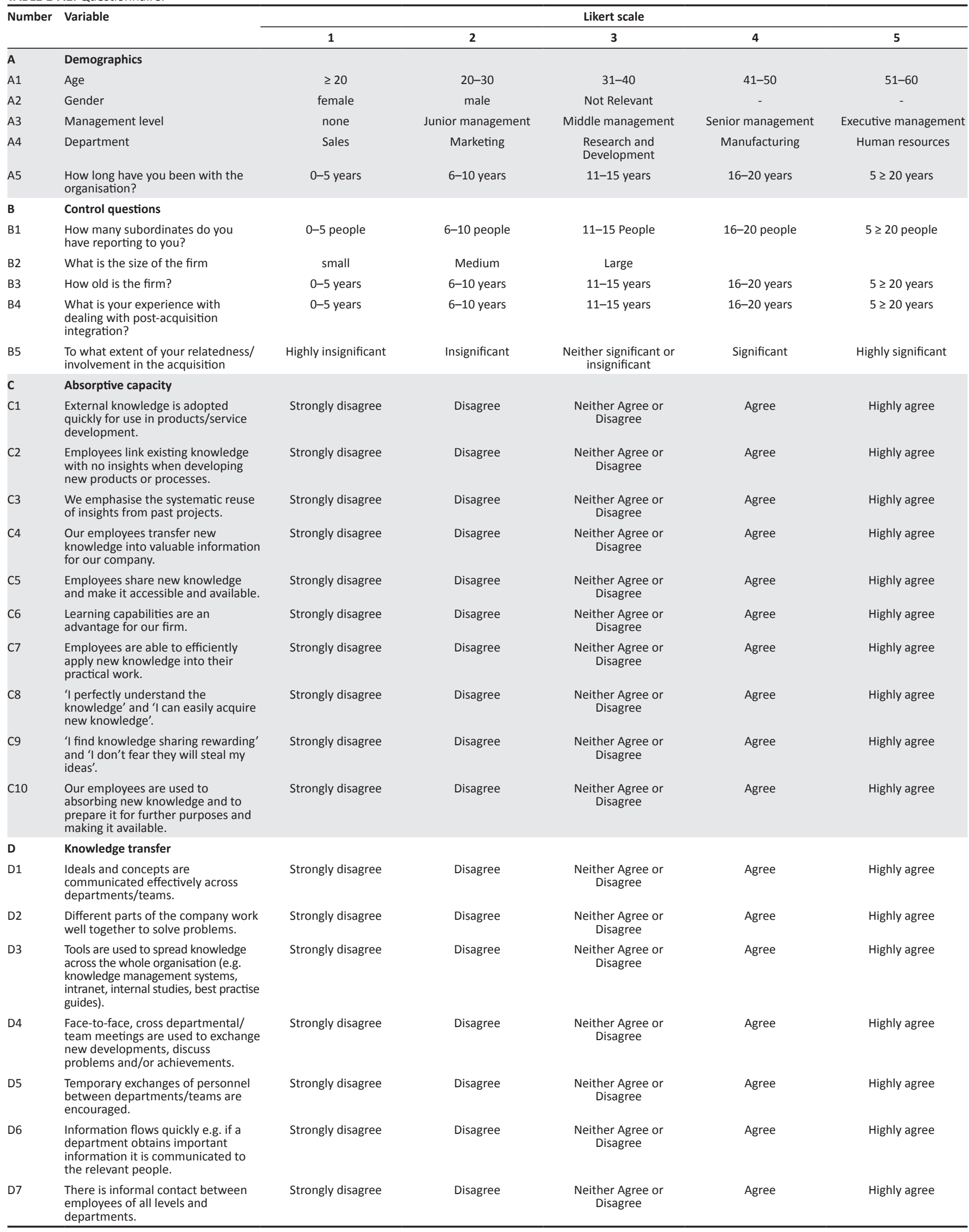


TABLE 1-A1 (Continues...): Questionnaire.

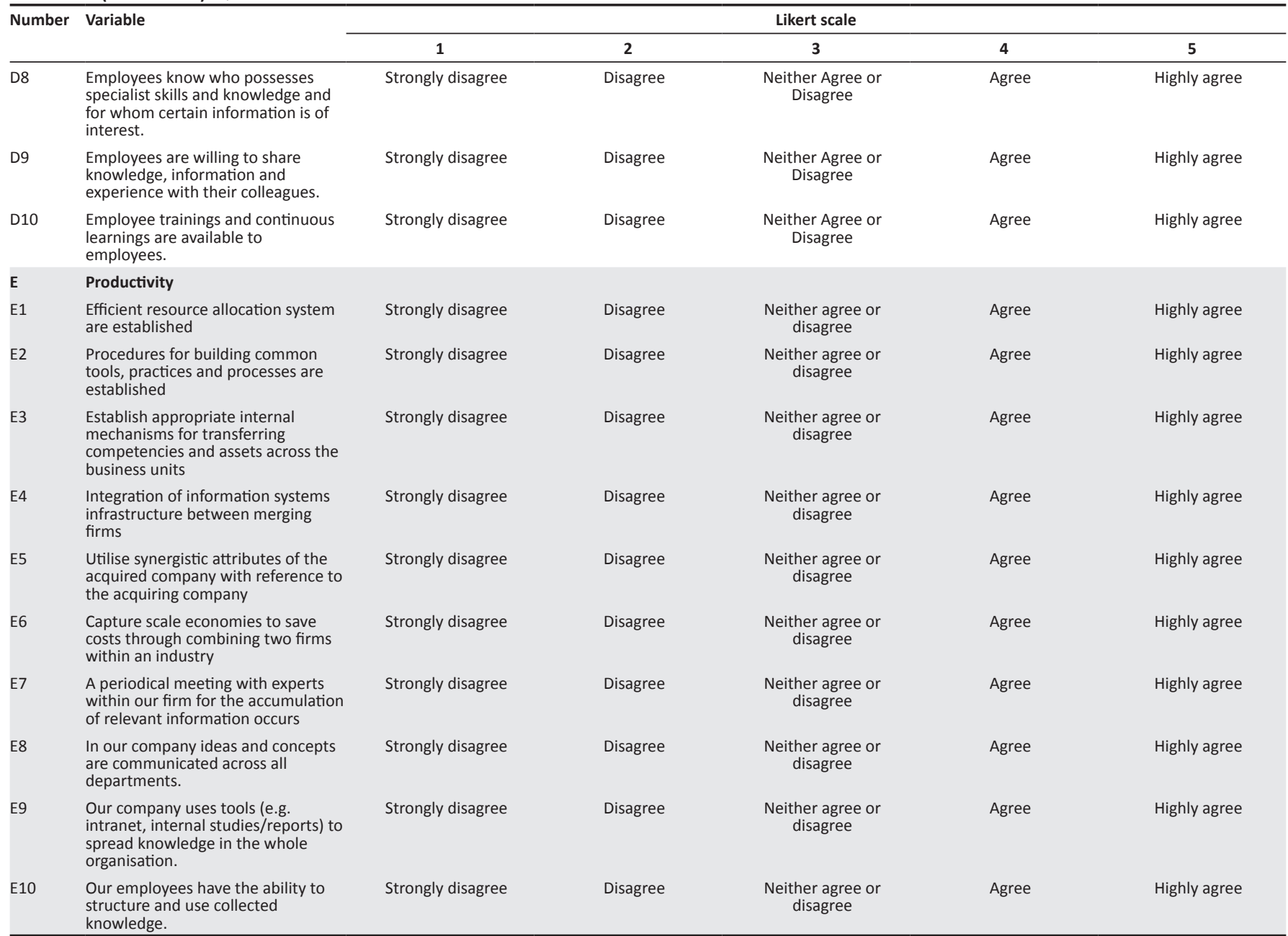

Source: Adapted from: Oldford and Otchere, (2016); Yang and Rui (2009); Flatten, Engelen, Zahra, and Brettel (2011); Zahra and George (2002); Hurtado-Ayala and Gonzalez-Campo (2015); Junni and Sarala (2013); Teece (2016); Sarala et al., (2016); Bernad et al., (2010); Li et al. (2016).

Note: Please see the full reference list of the article, Pillay, S., Chiba, M.D., Verachia, A., \& Mthombeni. M. (2021). Mergers and acquisitions in emerging markets: What drives absorptive capacity in target firms? South African Journal of Business Management, 52(1), a2039. https://doi.org/10.4102/sajbm.v52i1.2039, for more information. 